\title{
EXCHANGE RATE FLUCTUATION IN INDONESIA: VECTOR ERROR CORRECTION MODEL APPROACH
}

\author{
Fitra Prasapawidya Purna, Puguh Prastyo Mulyo, M Roqi Azza Bima \\ Pusat Pengembangan Ekonomi \\ Fakultas Ekonomi dan Bisnis, Universitas Muhammadiyah Yogyakarta \\ Correspondence E-mail: fitra.prasapa93@gmail.com
}

Received: July 2016; Accepted: October 2016

\begin{abstract}
Exchange rate in the last few years has been fluctuating highly. A number of variables were used in this research to analyze which variable has impact on exchange rate. The variables used were export, import, money supply and Bank Indonesia rate, for the period of January 2010 until September 2015, utilizing vector error correction model or VECM estimation method. The results indicate that in the long run, some variables such as import and money supply have significant correlations to exchange rate with positive and negative impact respectively, while export and BI rate have no significant correlation to exchange rate with negative and positive impact respectively. In the short run, all variables bear significant influence on exchange rate except money supply, whereas import, money supply and BI rate maintain a positive relationship with the exchange rate. Meanwhile, export has a negative influence on exchange rate. For impulse response and forecast error variance decomposition, the variable which induced the most shock to exchange rate was import.
\end{abstract}

Keywords: exchange rate, VECM

JEL Classifications: F31, C32

Abstrak: Nilai tukar dalam beberapa tahun terakhir sangat berfluktuasi. Sejumlah variabel digunakan dalam penelitian ini untuk menganalisis variabel mana yang berpengaruh terhadap nilai tukar. Variabel yang digunakan adalah ekspor, impor, uang beredar dan suku bunga Bank Indonesia, untuk periode Januari 2010 sampai September 2015, dengan menggunakan model koreksi kesalahan vektor atau metode estimasi VECM. Hasil penelitian menunjukkan bahwa dalam jangka panjang, beberapa variabel seperti impor dan jumlah uang beredar memiliki korelasi yang signifikan terhadap ER dengan dampak positif dan negatif masing-masing, sedangkan tingkat ekspor dan BI tidak memiliki korelasi signifikan terhadap ER dengan dampak negatif dan positif masing-masing. Dalam jangka pendek, semua variabel berpengaruh signifikan terhadap nilai tukar kecuali jumlah uang beredar, sedangkan impor, uang beredar dan suku bunga BI menjaga hubungan positif dengan nilai tukar. Sementara itu, ekspor memiliki pengaruh negatif terhadap nilai tukar. Untuk respon impuls dan dekomposisi varians kesalahan estimasi, variabel yang menginduksi shock yang paling besar bagi nilai tukar adalah impor.

Kata kunci: nilai tukar, VECM

Klasifikasi JEL: F31, C32 


\section{INTRODUCTION}

Two thousands and fifteen is the year when exchange rate of Indonesia fluctuated more fluently in the high point. We can't deny the existence of international market that influences the changes of the exchange rate. Especially, when we talk about the upcoming of Asean Economic Community in the end of that year, it should relate to the export and import between countries. The instability of exchange rates will affect the flow of capital or investment and international trade (Ulfia and Aliasaddin, 2011).
Such a strong currency is needed to face the obstacles that may occur in the middle of the event. Cause it will not just affect the country but also the citizens even the one who stays in the villages. Even the slightest change can make people suffer or delight. The change of currency value is affected by trade balance with other countries which using the big amount of money especially using US Dollars as its trade's money. A stable currency value indicates that the country has a relatively good economic condition or stable. (Muchlas and Agus R, 2015).

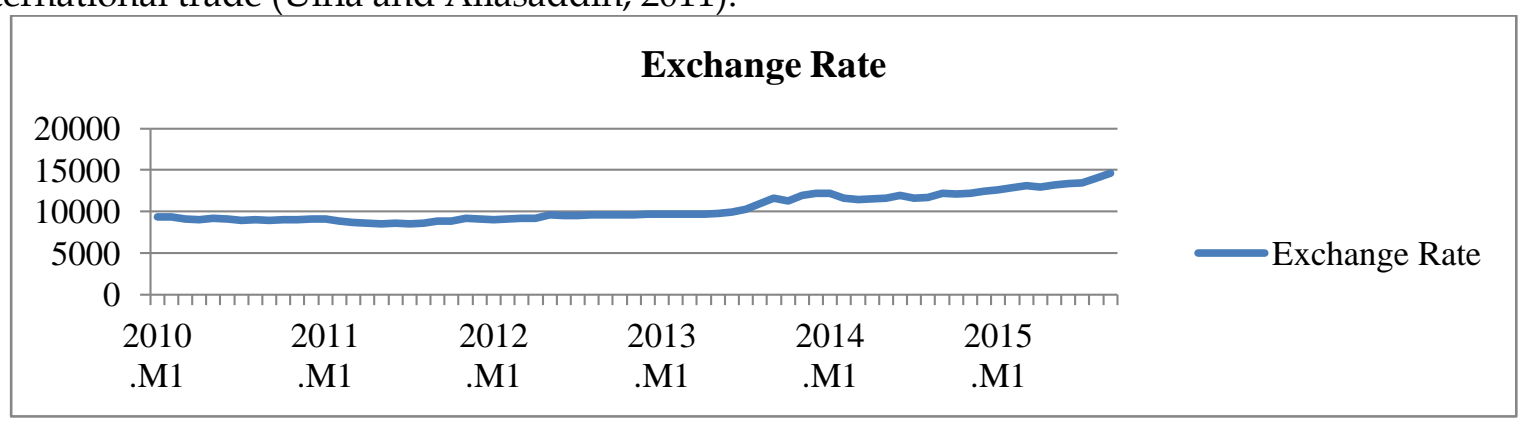

Resource: Bank Indonesia (calculated)

The changes of exchange rate in these last years can be seen in the graph above as its value fluctuated in the high point through 2013-2015 around Rp12.000-14.000 as before it just fluctuate around Rp8.000-10.000.

Some researcher has conducted their research and published their finding about the influences of variables such as export, import, money supply, Bank Indonesia rate, inflation rate, and others toward exchange rate. Some findings were significant and others not. Such as RR Suci Palasari (2015) in her research about the Influence of exports, imports, inflation rate, and the Interest Rate toward Exchange Rate explain the multiple linear regression method that partially exports negative effect significantly, import significant positive effect, interest rates positive and significant on the rupiah. While the inflation rate does not significantly affect and the interest rate is the dominant variable.

By those backgrounds the researcher wants to analyze some variables that can influence the fluctuations of exchange rate, there are export, import, money supply, and Bank Indonesia rate in the period of the data from January 2010 until September 2015. With the title of "Analysis of Exchange Rate Fluctuation Using Vector Error Correction Model (VECM) From 2010 To 2015"

\section{RESEARCH METHOD}

This study adopted a Vector Error Correction Model (VECM) to examine the relationship between exchange rate and macroeconomic variable in Indonesia. Model developed and applied in this study as follow:

$\mathrm{ERt}=\sum_{\mathrm{j}=1}^{\mathrm{n}} \mathrm{ER}_{\mathrm{t}-\mathrm{j}}+\sum_{\mathrm{j}=1}^{\mathrm{n}} \mathrm{EXP}_{\mathrm{t}-\mathrm{j}}+\sum_{\mathrm{j}=1}^{\mathrm{n}} \mathrm{IMP}_{\mathrm{t}-\mathrm{j}}+$ $\sum_{\mathrm{j}=1}^{\mathrm{n}} \mathrm{M} 2_{\mathrm{t}-\mathrm{j}}+\sum_{\mathrm{j}=1}^{\mathrm{n}} \mathrm{BRT}_{\mathrm{t}-\mathrm{j}}+\varepsilon_{1 \mathrm{t}}$

It aims to examine the long run and short run relationship between Exchange rate(ER) with four macroeconomic variables, namely Export (EXP), Import (IMP), money supply (M2), and Bank Indonesia Rate (BRT). To properly specify the VECM model, this research followed the standard procedure of time series analyses. By following these procedures:

1. Descriptive Statistic

2. Unit Roots Test - Augmented Dickey Fuller Test

3. Lag Length Criteria Test

4. VAR Stability Test - Roots of Characteristic Polynomial

5. Correlation Matrix - Johansen Julius Cointegration Test

6. Pairwise Granger Causality Test

7. VECM Estimation

8. Impulse Response

9. Variance Decomposition Test. 
In the detail that mentioned technique will be explain in the following explanation.

1. Descriptive statistic.

Descriptive statistic supposed to figure out research data. Consist of descriptive analysis as follows:
a. Examining the value of Mean (average)
b. Examining the value of Maximum
c. Examining the value of Minimum

2. Unit root test.

The stationary test conducts of the variables to avoid spurious result. There are several methods for testing the presence of unit roots. The most widely used method is Augmented Dickey Fuller (ADF) and Philips-Perron (PP). ADF is applied when the error terms $\left(e_{t}\right)$ are correlated. ADF performed by adding the lagged values of the dependent variable $\Delta \mathrm{Y}_{\mathrm{t}-}$ the null hypothesis for ADF test for unit roots test is $a_{1}=0$ Gujarati (1995). For estimate ADF the following regression is for $\mathrm{ADF}$ following:

$$
\Delta_{Y t}=\beta_{1}+\beta_{2 t}+\delta_{Y t}+a \sum_{i=1}^{m} \Delta Y t-1+\varepsilon
$$

Where $\varepsilon t$ is a white noise error term and $\Delta \mathrm{Y}_{\mathrm{t}-1}=\left(\mathrm{Y}_{\mathrm{t}-1}-\Delta \mathrm{Y}_{\mathrm{t}-2}\right)$ and so on are the number of lagged difference term which is empirically determined (Gujarati, 1995). ADF also has its own critics. Paramaia and Akway (2008) claimed that the ADF test has good size but poor power properties. Meanwhile another test is PP test. This test controls the higher-order serial correlation. PP test use on parametric statistical methods and avoid the use of adding lagged difference terms in ADF test. The null hypothesis for PP test is $\beta_{1}=0$. The PP test is relatively better, but has very poor size in the presence of $\mathrm{MA}$ processes. The following equation represent for PP test (Jeong; Fanara; Mahome, 2002).

$$
Y t=\beta 0+\beta t Y_{t-1}+e t
$$

In this test the researcher use a scale of confidence $5 \%$. It means that when the value is under the scale of confidence then the $\mathrm{Ha}$ is accepted or there is a stationary from variable.
3. Determining lag length

The determination of the lag length, used to determine the optimal amount of lag that will be used in a stationary test. If the lag length used in a stationary test too little, the residuals regression will not show the white noise because the model can't accurately estimate the actual error. Consequently, Y and standard error cannot be estimated correctly. But, if input too much lag, it can reduce the ability to reject $\mathrm{H}_{0}$, because if adding to much additional parameters can reduce the degrees of freedom (Ajija,2011). To knowing the right criteria in Stationery test, there is the right criteria to determine lag following:

Aike Information Criteria $($ AIC $)=-2\left(\begin{array}{c}1 \\ T\end{array}\right)+2(\mathrm{k}+\mathrm{T})$

Schwarz Information Criterion $(S I C)=-2\left(\frac{1}{T}\right)+\mathrm{k} \frac{\log (T)}{T}$

Hannan-Quinn Information Criterion $(H Q)=$

Where:

$$
-2\left(\frac{1}{T}\right)+2 \mathrm{k} \log \left(\frac{\log (T)}{T}\right)
$$

1 = Value function log likelihood

$\mathrm{T}=$ Total of observation

$\mathrm{k}=$ Parameter are estimated

4. VAR stability test.

VAR stability test conduct to know the stability of VAR variable, because if the VAR variable is unstable the prediction of IRF and Variance Decomposition is invalid. VAR is stable if the modulus value of roots less than $1(<1)$ (Basuki, 2014).

5. Correlation Matrix - Johansen Julius cointegration test.

The co-integration test conducts to determine whether the time series of these variables display a stationary process in a linear combination. Co-integration means that data from a linear combination of two variables can be stationary despite those variables being individually non-stationary (Gujarati, 1995). The Johansen (1991) method of multivariate co-integration is employed. A finding of co-integration implies the existence of a long-term relationship between the dependent and the independent variables. If there is at least one cointegration relationship among the variables, then the causal relationship among these 
variables can be determined by estimating the VECM.

The Johansen and Juselius method uses two test to determine the number of cointegration vectors (Adebiyi, 2007), namely the "Likelihood Ratio Trace test-LRT" and the "Maximum Eigenvalue test-ME" The likelihood trace statistic expressed as:

$$
\mathrm{LRT}=-\mathrm{T} \sum_{\mathrm{i}-\mathrm{i}+1}^{\mathrm{n}} \ln (1-\mu \mathrm{i})
$$

For this null hypothesis, it is said that the number of co-integration vectors is less than or equal to $r$, in which $r$ is $0,1,2,3 \ldots$ So on. The alternative hypothesis against this is that $r=n$. Meanwhile the Maximum Eigenvalue test is formulated as:

$$
\mathrm{ME}=-\mathrm{T} \ln \left(1-\mu_{\mathrm{t}}\right)
$$

The null hypothesis is that the existence of $r$ co-integration vector and the alternative hypothesis is $r+1$ co-integration vectors. The scale of confidence that used in this research is $5 \%$, it means that when the value under the scale of confidence then Ha is accepted or there is a co-integration between variables.

6. Pair Wise Granger causality test.

According to Granger (1988), the existence of co-integrating vectors implies that granger causality exists at least in one direction. A granger variable causes the other variable only if it assists its future value. In co-integrated series variables might be share similar stochastic trends. This research conducts Granger causality test to look for directional relationship among variables.

Gujarati (2003) stated that, there are three Granger interpretations: first unidirectional causality, second bilateral causality and third independence causality. Unidirectional causality occurs if dependent variable lag coefficience is significant while all independent variable lag coefficience is zero. Bilateral causality occurs if all lag coefficient of both dependent and independent variables are significant.

The scale of confidence that used in this research is $5 \%$, it means that when the value is under $5 \%$ then $\mathrm{Ha}$ is accepted or there is effect from on variable to another variable.
7. Vector Error Correction Model (VECM) estimation.

Vector Error Correction model (VECM) is a restricted VAR designed for non-stationary series are known to be cointegration. VECM has co-integration relation built into specification cause of that it restricted the long-run behavior of the endogenous variable to converge to their co-integration relationship while allowing for short run adjustment dynamics. The cointegration term is known as the error term since the deviation from long-run equilibrium is corrected gradually through a series of partial short-run adjustment. Consider a two variable system with one co-integration equation and no lagged difference terms. The co-integration equation is:

$$
\mathrm{y}_{2, \mathrm{t}}=\beta \mathrm{y}_{1, \mathrm{t}}
$$

The corresponding VECM is:

$$
\begin{aligned}
& \Delta \mathrm{y}_{1, \mathrm{t}}=\mathrm{a}_{1}\left(\mathrm{y}_{2}, \mathrm{t}-1-\beta \mathrm{y}_{1, \mathrm{t}-1}\right)+\varepsilon_{1, \mathrm{t}} \\
& \Delta \mathrm{y}_{2, \mathrm{t}}=\mathrm{a}_{2}\left(\mathrm{y}_{2, \mathrm{t}-1}-\beta \mathrm{y}_{1, \mathrm{t}-\mathrm{1}}\right)+\varepsilon_{1, \mathrm{t}}
\end{aligned}
$$

The only right side variable is the error correction term. In long run equilibrium, the term is zero. If $\mathrm{y}_{1}$ and $\mathrm{y}_{2}$ deviate from the long run equilibrium, the error correction term will be nonzero and each variable adjusts to partially restore the equilibrium relation. The coefficient $a_{i}$, measure the speed of adjustment of the i-th endogenous variable towards equilibrium.

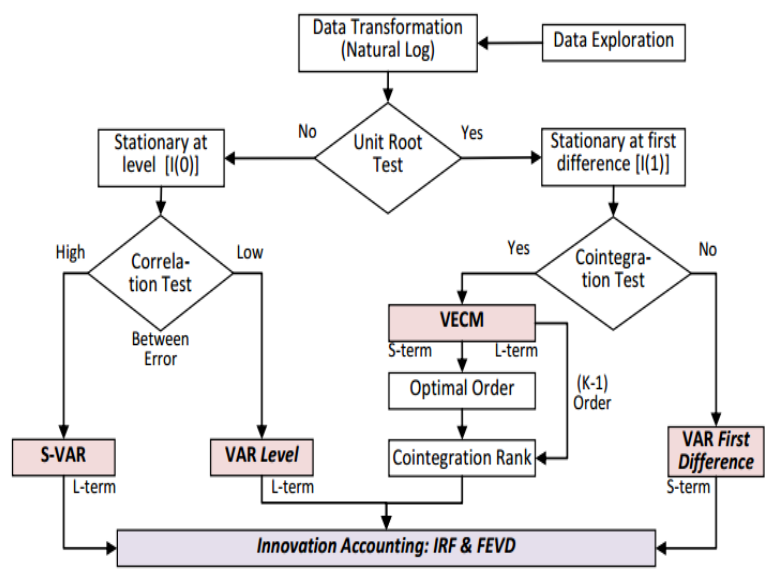

Source: Gujarati (2004) 


\section{Figure 1 VAR Process Analyses}

The level of confidence that used in this research is $5 \%$, it means that when the value is fewer than $5 \%$ or the value of $t$ stats more than $\mathrm{t}$-table which the value of $\mathrm{t}$ table is 1.67 then Ha is accepted or there is significant impact from the variable.

8. Impulse response.

For the function of IRF expectation kperiod ahead and the error prediction variable cause the innovations of others variable. Thus the duration effect shock of a one variable to others variable until the effect of shock is disappear or return to equilibrium can be seen and knowing. (Ajija, 2011)

9. Variance decomposition.

Variance Decomposition or also Forecast error variance decomposition is a device on the VAR model which separates the variation of the number variables in the estimate into its component parts into a variable shock or innovation, with the assumption the variable not mutually correlated. Then the variance decomposition will provide information on the proportion of the movement the shock effect to the shock on others variables in the current period and future periods (Ajija, 2011).

\section{RESULTS AND DISCUSSION}

This part will explain the findings from the research and some explanations through the data that has been analyzed and will reveal all things according to the research.

1. Descriptive statistic.

Descriptive statistics represents the entire population or sample in the study. It explains data central tendency and dispersion measurement. Eviews 7 is used as the econometrics tool to analyze the data. Eventually, this study finds the following descriptive statistics:

Table 1 Descriptive Statistic

\begin{tabular}{lccccc}
\hline \multicolumn{1}{c}{ ER } & EXP & IMP & M2 & BRT \\
\hline Mean & 10390.62 & 15018.52 & 13338.89 & 3200908 & 6.684783 \\
\hline Median & 9615 & 15340.48 & 13986.65 & 3207908 & 6.5 \\
\hline Maximum & 14657 & 18530.80 & 16749.95 & 4508603 & 7.75 \\
\hline Minimum & 8508 & 10540.03 & 8675.846 & 2066481 & 5.75 \\
\hline Std. Dev & 1652.367 & 1840.137 & 1946.309 & 720777.8 & 0.698807 \\
\hline Skewness & 0.749878 & -0.376051 & -0.684937 & 0.79782 & -0.006085 \\
\hline Observation & 69 & 69 & 69 & 69 & 69 \\
\hline
\end{tabular}

Resource: Data Processing

Table 1 defines the descriptive statistics of all variables with regards to changes in ER, EXP, IMP, M2, and BRT. The table shows the following results: ER's Mean, Median, Maximum, and Minimum values are, respectively, 10390.62, 9615, 14657, and 8508. Secondly, EXP's Mean, Median, Maximum, and Minimum values are, respectively, 15018.52, 15340.48, 18530.80, and 10540.03. Thirdly, the IMP's Mean, Median, Maximum, and Minimum values are, respectively, 13338.89, 13986.65, 16749.95, and 8675.846. Fourthly, M2's Mean, Median, Maximum, and Minimum values are, respectively, 3200908, 3207908,
4508603, and 2066481. Lastly, BRT's Mean, Median, Maximum, and Minimum values, respectively, 6.684783, 6.5, 7.75, and 5.75. The results indicate that all variables show positive mean. The values of Skewness for EXP, IMP, and BRT are negative, they are, respectively, -0.376051, -0.684937, and 0.006085 . While the values for ER and M2 are positive, 0.749878 and 0.79782, respectively.

2. Unit Roots Test - Augmented Dickey Fuller test.

In the econometric examination model used is VAR/VECM model, the first test performed is stationary test to build the proper econometrics model. The unit root 
test is conducted by observing the value of Akaikie Information Criterion (AIC) and Schwarz Criterion (SC) through AugmentedDickey-Fuller Test (ADF-test) at level and at first difference level. If the t-statistics is value bigger than the critical value, the data is stationary at level and can be analyzed using VAR methods. But, if the t-statistics value is smaller than the critical value, then the data is not stationary at Level. ADF-test is used to examine the stationary data and lag length of the five variables in this study in level and first difference. From the data processing program using Eviews 7 program, unit root test results are shown in the table below.

Table 2 Unit Root Test - Augmented Dickey Fuller (ADF-test)

\begin{tabular}{|c|c|c|c|c|c|c|}
\hline \multirow{2}{*}{$\begin{array}{c}\text { Test } \\
\text { Variable }\end{array}$} & \multicolumn{6}{|c|}{ ADF } \\
\hline & $\frac{\text { Level }}{\text { t-statistic }}$ & Prob & Note & First Difference & Prob & Note \\
\hline ER & 2.178403 & 0.9999 & Not stationer & -6.851359 & 0.0000 & Stationer \\
\hline EXP & -2.18727 & 0.2128 & Not Stationer & -12.70672 & 0.0000 & Stationer \\
\hline IMP & -2.675923 & 0.0835 & Not Stationer & -8.834403 & 0.0000 & Stationer \\
\hline M2 & 0.74766 & 0.9924 & Not Stationer & -10.64628 & 0.0000 & Stationer \\
\hline BRT & -0.774254 & 0.8197 & Not Stationer & -5.971178 & 0.0000 & Stationer \\
\hline
\end{tabular}

Resource: Data Processing

The results in the table 2 above show that the values of Exchange Rate (ER), export (EXP), import (IMP), money supply (M2), and Bank Indonesia rate (BRT) are stationary in first difference. Because the five variables are in first difference ER, EXP, IMP, M2, and $\mathrm{BRT}$, therefore, the variables must be transformed into first difference. The defined value in the following equation is:

$$
\begin{gathered}
D E R_{t}=A_{0}+A 1 D E X P t_{-2}+A_{2} D_{1 M P t_{-2}}+ \\
A_{3} D M 2 t_{-2}+A_{4} D B R T t_{-2}+e_{t}
\end{gathered}
$$

In which $\mathrm{D}$ is at first difference, which means that DER represents the first difference of exchange rate, DEXP represents the first difference of export, DIMP represents the first difference of import, DM2 represents the first difference of money supply, and DBRT represents the first difference of Bank Indonesia rate.

3. Lag Length criteria test.

The second step for establishing the presence of a long-run relationship among the variables is to determine the optimal lag length for the VAR system. Lag-length misspecification for the VAR model often generates auto correlated errors. By determining lag optimum, it will determine the criteria of final prediction error correction (FPE) or the total of AIC, SIC, and $\mathrm{HQ}$ which is minimum between some of the lags.

Table 3 Lag Length Criteria

\begin{tabular}{ccccccc}
\hline Lag & LogL & LR & FPE & AIC & SC & HQ \\
\hline 0 & -2179.676 & NA & $2.78 \mathrm{e}+24$ & 70.47343 & $70.64497^{*}$ & 70.54078 \\
\hline 1 & -2142.612 & 66.95461 & $1.89 \mathrm{e}+24$ & 70.08426 & 71.11352 & $70.48838^{*}$ \\
\hline 2 & -2115.451 & $44.6843^{*}$ & $1.79 \mathrm{e}+24^{*}$ & $70.01455^{*}$ & 71.90153 & 70.75543 \\
\hline 3 & -2094.820 & 30.61354 & $2.15 \mathrm{e}+24$ & 70.15549 & 72.90018 & 71.23313 \\
\hline 4 & -2074.852 & 26.40935 & $2.73 \mathrm{e}+24$ & 70.31781 & 73.92022 & 71.73221 \\
\hline 5 & -2051.537 & 27.07515 & $3.31 \mathrm{e}+24$ & 70.37218 & 74.83230 & 72.12333 \\
\hline
\end{tabular}

*indicates lag order selected by criterion

LR : sequential modified LR test statistic (each test at 5 percent level)

FPE : Final Prediction error

AIC : Akaike information criterion

SC : Schwarz information crierion

HQ : Hannan - Quinn information criterion

Resource: Data Processing 
The table shows the result of automatic lag length determination by Eviews 7. It shows that based on the value of Schwarz information criterion (SC) match in lag 0, which is 70.64497, the value of HannanQuinn Information (HQ) match in lag 1, which is 70.48838, LR statistics, Final Prediction error (FPE), and AIC match in lag 2, which are 44.68246,1.79e+24, and 70.01455, respectively. Automatic Eviews 7 lag length determines lag 2 as proper lag length in VECM estimation.
4. VAR Stability Test - Roots of Characteristic Polynomial.

After determining the lag length criteria to know the proper lag length for VAR estimation, the next step is to know the VAR stability test using Roots of Characteristic Polynomial. Roots of Characteristic Polynomial is performed to know whether the variable in VAR is stable to test in a VAR model. If the value of Roots and Modulus polynomial is less than $1(<1)$ it means the variable is sufficient to be tested in a VAR model. The table below shows the result of polynomial test.

Table 4 Roots of Characteristic Polynomial

\begin{tabular}{lc}
\hline Roots & Modulus \\
\hline$-0.227858-0.644577 \mathrm{i}$ & 0.683666 \\
\hline$-0.227858+0.644577 \mathrm{i}$ & 0.683666 \\
\hline$-0.447781-0.437948 \mathrm{i}$ & 0.626344 \\
\hline$-0.447781+0.437948 \mathrm{i}$ & 0.626344 \\
\hline 0.560511 & 0.560511 \\
\hline$-0.271225-0.403905 \mathrm{i}$ & 0.486521 \\
\hline$-0.271225+0.403905 \mathrm{i}$ & 0.486521 \\
\hline $0.281102-0.298921 \mathrm{i}$ & 0.410332 \\
\hline $0.281102+0.298921 \mathrm{i}$ & 0.410332 \\
\hline-0.258468 & 0.258468 \\
\hline
\end{tabular}

No root lies outside the unit circle.

Resource: Data processing

Based on table 4 above, all of the values of Roots and Modulus are less than one $(<1)$, and based on VAR, it satisfies the stability control which mentioned that no root lies outside the unit circle. It means that the variable is sufficient to test in a VAR model.

5. Correlation Matrix - Johansen Julius Cointegration Test.

Co-integration test is conducted by examining the stationary value from each variable in this research. The variable can be integrated or not integrated, if the variable is integrated, it means that the variable has a long-term relationship and continued with VECM model, but if it is not co-integrated, the model will be tested in VAR First Difference (FDVAR). Co-integration test is examined using the Johansen Juselius Cointegration Test. In order to find out the number of co-integration vector, Trace statistics and Maximal Eigen value tests were used. In this study, the criteria to determine co-integration test is based on the probability, if the probability more than $a>$ 0.05 , its means that the co-integration is rejected. The results of the Johansen's Trace and Max Eigen value test are shown in the table 4.5 below.

Table 5 Co-integration test Johansen Juselius Test

\begin{tabular}{|c|c|c|c|c|c|c|c|}
\hline Model & $\begin{array}{l}\text { Hypothe- } \\
\text { sized }\end{array}$ & $\begin{array}{c}\text { Trace } \\
\text { Statistic }\end{array}$ & Prob. & $\begin{array}{c}\text { Max - } \\
\text { Eigen } \\
\text { Statistic }\end{array}$ & Prob. & Variable & Result \\
\hline \multirow{3}{*}{$\begin{array}{l}\text { Lag } \\
\text { length } \\
=2\end{array}$} & None* & 140.8385 & 0.0000 & 62.09591 & 0.0000 & ER & \multirow{3}{*}{$\begin{array}{c}\text { Trace statistic } \\
\text { showed there are } 5 \\
\text { co-integration and } \\
\text { Max Eigen statistic }\end{array}$} \\
\hline & At most 1 & 78.74261 & 0.0000 & 32.44752 & 0.0109 & EXP & \\
\hline & At most 2 & 46.29510 & 0.0003 & 30.54058 & 0.0018 & IMP & \\
\hline
\end{tabular}




\begin{tabular}{cccccccc}
\hline Model & $\begin{array}{c}\text { Hypothe- } \\
\text { sized }\end{array}$ & $\begin{array}{c}\text { Trace } \\
\text { Statistic }\end{array}$ & Prob. & $\begin{array}{c}\text { Max - } \\
\text { Eigen } \\
\text { Statistic }\end{array}$ & Prob. & Variable & Result \\
\hline & & & & & & \\
\cline { 2 - 5 } & $\begin{array}{c}\text { At most 3 } \\
*\end{array}$ & 15.75452 & 0.0457 & 9.043606 & 0.2825 & M2 & $\begin{array}{c}\text { showed there are 3 } \\
\text { co-integration } \\
\text { vectors }\end{array}$ \\
\cline { 2 - 5 } & $\begin{array}{c}\text { At most } 4 \\
*\end{array}$ & 6.710912 & 0.0096 & 6.710912 & 0.0096 & BRT & \\
\hline
\end{tabular}

Source: Data Processing

variables of ER, EXP, IMP, M2, and BRT have

Table 5 above shows the results of Johansen Juselius Co-integration test. The MacKinnon-Haug-Mihelis p-values are 0.000 $<\mathrm{a}=0.05$, therefore, it rejects $\mathrm{H}_{0}$ and accepts $\mathrm{Ha}$, or the model is significant. Trace test statistic showed 5 co-integration and Max Eigen statistics showed 3 co-integration vectors among the variables at $=0.05$. In other words, there is co-integration among ER, EXP, IMP, M2, and BRT for the period of January 2010 - September 2015. Based on Johansen Juselius Cointegration Test, it a long run co-integration, the next method is VECM test for long run and short run.

6. Pairwise Granger Causality Test.

Granger causality test is conducted to know whether of each the variables have causality relationship or not. In other words, every variable has causality to other variable and can become the exogenous variable and endogenous variable. This research uses $\alpha=$ 5 percent as indicator. The result of Pairwise Granger Causality test is shown in the table 5.6 below.

indicates that five co-integration test mean

Table 6 Result Pairwise Granger Causality Test

\begin{tabular}{llc}
\hline Dependent Variable & \multicolumn{1}{c}{ Independent Variable } & Probability \\
\hline \multirow{2}{*}{ ER } & EXP & $0.0115^{*}$ \\
\cline { 2 - 3 } & IMP & 0.1694 \\
\cline { 2 - 3 } & M2 & $0.0211^{*}$ \\
\cline { 2 - 3 } & BRT & $0.0346^{*}$ \\
\hline \multirow{2}{*}{ EXP } & ER & 0.3336 \\
\cline { 2 - 3 } & IMP & $0.0123^{*}$ \\
\cline { 2 - 3 } & M2 & 0.9895 \\
\cline { 2 - 3 } & BRT & 0.6715 \\
\hline IMP & EXP & 0.6989 \\
\cline { 2 - 3 } & ER & 0.1545 \\
\cline { 2 - 3 } & M2 & 0.8966 \\
\cline { 2 - 3 } & BRT & $0.0480^{*}$ \\
\hline MXP & IMP & $0.0060^{*}$ \\
\cline { 2 - 3 } & ER & 0.2536 \\
\cline { 2 - 3 } & BRT & 0.0676 \\
\hline BRT & EXP & 0.3276 \\
\cline { 2 - 3 } & IMP & 0.1870 \\
\cline { 2 - 3 } & M2 & $0.0411^{*}$ \\
\cline { 2 - 3 } & ER & 0.5375 \\
\hline
\end{tabular}

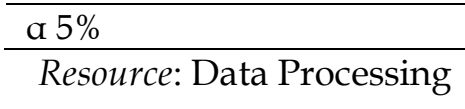

Table 6 shows that the result for ER as dependent variable, it has 3 significant independent variables that influence it statistically, they are, EXP, M2, and BRT which their value are $0.0115,0.0211$, and 0.0346 ,but with ER as independent variable for those variable as independent, there was no significant influence as the value, respectively, 0.336, 0.0676, and 0.5375. It means $\mathrm{HO}$ is rejected, it means there is 
unidirectional relationship between EXP to ER, M2 to ER, and BRT to ER.

Variable EXP is statistic but not significantly influence to IMP but IMP is statistic and significantly influence to EXP which shown from the probability values respectively 0.06989 and 0.0123 , it means $\mathrm{H} 0$ is rejected and can be concluded that there is unidirectional relationship between IMP to EXP.

Variable IMP is statistic but not significantly influence to BRT but BRT is statistic and significantly influence to IMP which shown from the probability values respectively 0.1878 and 0.0480 , it means $\mathrm{H} 0$ is rejected and can be concluded that there is unidirectional relationship between BRT to IMP.

Variable M2 is statistic but not significantly influence to EXP but EXP is statistic and significantly influence M2 which shown from the probability values respectively 0.9895 and 0.0060 , it means $\mathrm{H} 0$ is rejected and can be concluded that there is unidirectional relationship between EXP to M2.

Variable BRT is statistic but not significantly influence to M2 but $\mathrm{M} 2$ is statistic and significantly influence BRT which shown from the probability values respectively 0.3276 and 0.0411 , it means $\mathrm{H} 0$ is rejected and can be concluded that there is unidirectional relationship between M2 and BRT.

Variable ER is statistic but not significant influence to IMP and vice versa that is shown from the probability values respectively $(0,1545)$ and $(0.1694)$, it means $\mathrm{HO}$ is accepted can be concluded between both variables that there is no causality relationship.

Variable IMP is statistic but not significant influence to M2 and vice versa that is shown from the probability values respectively 0,2536 and 0.8966 , it means $\mathrm{H} 0$ is accepted can be concluded between both variables that there is no causality relationship.

Variable EXP is statistic but not significant influence to BRT and vice versa that is shown from the probability value respectively 0,1670 and 0.6715 which means that $\mathrm{H} 0$ is accepted, it can be concluded that between both variables there is no causality relationship.

\section{VECM Estimation.}

VECM test result will get the long run and short-run relationships between the dependent variable and independent variable. In VECM model will determine the long run and short-run between DER, DEXP, DIMP, DM2, and DBRT. This study uses lag 2 , based on lag length criteria, it is determined that the result of DER is the dependent variable and DEXP, DIMP, DM2, and DBRT are set as independent variables. Table 4.7 below shows the long-run and short-run relationship between Exchange rate (DER) as dependent variable and another variable as independent variable, the result is as follows:

Table 7 VECM Estimate Long-Run

\begin{tabular}{ccc}
\hline & Long-Term & \\
\hline Variable & Coefficient & T-Statistic \\
\hline EXP(-1) & -0.141717 & -0.86078 \\
\hline IMP(-1) & 0.518045 & $3.01729^{* *}$ \\
\hline M2(-1) & -0.002787 & $-9.60177^{* *}$ \\
\hline BRT(-1) & 117.1374 & 0.51888 \\
\hline
\end{tabular}

Resource: Data Processing

Table 7 above is the summary from VECM analysis to see the influence of significant variable in long-run relationship. The result of long-run relationship from table 5.7 shows all independent variables which influence ER are, respectively, export (EXP), import (IMP), money supply (M2) and Bank Indonesia rate (BRT), with significant value of $\alpha>5$ percent, respectively $-0.86078,3.01729$, -9.60177 and 0.51888 .

The first normalized equation in Long-Run Estimate :

$E R=-0.141717 \operatorname{EXP}(-1)+0.518045 \operatorname{IMP}(-1)-$ 0.002787 M2 (-1) + 177.1374 BRT (-1)

According to the equation in VECM long run estimate, a long-run relationship among the variables is shown. Exchange rate shows positive values significantly to IMP and BRT and for EXP and M2 have negative value significantly. 
Table 8 VECM Estimate Short-run

\begin{tabular}{ccc}
\hline & Short-Run & \\
\hline Variable & Coefficient & T-Statistic \\
\hline CointEq1 & -0.220947 & $-3.57746^{* * *}$ \\
\hline $\mathrm{D}(\mathrm{ER}(-1))$ & 0.130575 & 1.01090 \\
\hline $\mathrm{D}(\mathrm{ER}(-2)$ & -0.077894 & -0.57305 \\
\hline $\mathrm{D}(\mathrm{EXP}(-1))$ & -0.062939 & $-2.00545^{* *}$ \\
\hline $\mathrm{D}(\mathrm{EXP}(-2))$ & -0.060601 & $-2.01186^{* *}$ \\
\hline $\mathrm{D}(\mathrm{IMP}(-1))$ & 0.058846 & 1.76672 \\
\hline $\mathrm{D}(\mathrm{IMP}(-2))$ & 0.088096 & $2.90443^{* * *}$ \\
\hline $\mathrm{D}(\mathrm{M} 2(-1))$ & 0.001031 & 1.20978 \\
\hline $\mathrm{D}(\mathrm{M} 2(-2))$ & 0.000453 & 0.58204 \\
\hline $\mathrm{D}(\mathrm{BRT}(-1))$ & 213.2985 & 0.96015 \\
\hline $\mathrm{D}(\mathrm{BRT}(-2))$ & 666.8306 & $2.92897^{* * *}$ \\
\hline $\mathrm{C}$ & 12.24113 & 0.25008 \\
\hline R-squared & 0.387970 & \\
\hline Adj. R-squared & 0.263297 & \\
\hline$* * * * * * \mathbf{1} \%, \mathbf{5} \%, \mathbf{1 0} \%$ & & \\
\hline
\end{tabular}

Resource: Data processing

Table 8 above is the summary from VECM analysis to see the influence and significant variable in short-run. In short run, export, import, and Bank Indonesia rate are significant and money supply is not significant, it means that in short-run and long-run some variables have influence to ER.
Export in $1^{\text {st }}$ and $2^{\text {nd }}$ lag is significant and negative to ER. Import in $2^{\text {nd }}$ lag is significant and positive to ER. Bank Indonesia rate in $2^{\text {nd }}$ lag is significant and positive to ER. Short run equation on VECM model is shown as follows:

The Second normalized VECM Short-Run Estimate:

\section{$D E R=12.24113+0.130575 D(E R(-1))-0.077894 D(E R(-2))-0.062939 D(E X P(-1))-0.060601 D(E X P(-$ $2))+0.058846 D(\operatorname{IMP}(-1))+0.088096 \mathrm{D}(\operatorname{IMP}(-2))+0.001031 \mathrm{D}(\mathrm{M} 2(-1))+0.000453 \mathrm{D}(\mathrm{M} 2(-$ 2))+213.2985D(BRT(-1))+666.8306D(BRT(-2) -0.220947CointEq1}

8. Impulse Response.

The function of Impulse Response is to track the response of a variable over time after a shock to the VAR system. Sims, 1992 in his book, Ajija, 2011 explains the function of IRF expectation k-period ahead and the error prediction variable caused by innovations of other variables. Thus, the shock effect duration of one variable to other variable up to the point when the effect of shock disappears or returns to equilibrium can be seen and known. The persistence of a shock indicates how quickly the system returns to equilibrium. Graph below shows the result of analysis on Impulse Response, as follows:

Response of ER to EXPORT

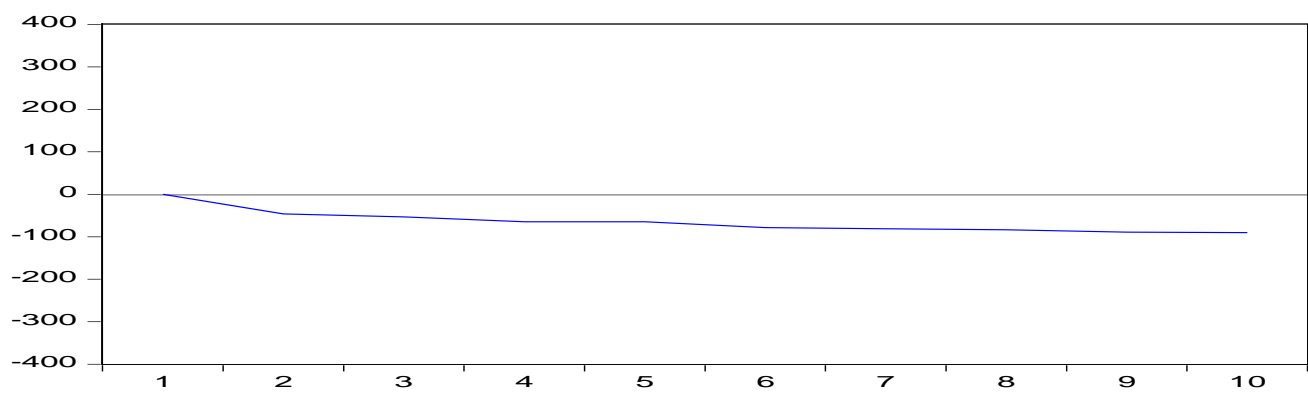

Resource: Data Processed

Figure 2 Response of ER to EXPORT 
From the graph above we can see the response of exchange rate toward the changes in export. In the $1^{\text {st }}$ period there was no change for exchange rate when export change, but after $2^{\text {nd }}$ period till $10^{\text {th }}$ period exchange rate value will decrease eventually especially between $1^{\text {st }}$ and $2^{\text {nd }}$ period. It means that export can strengthen the value

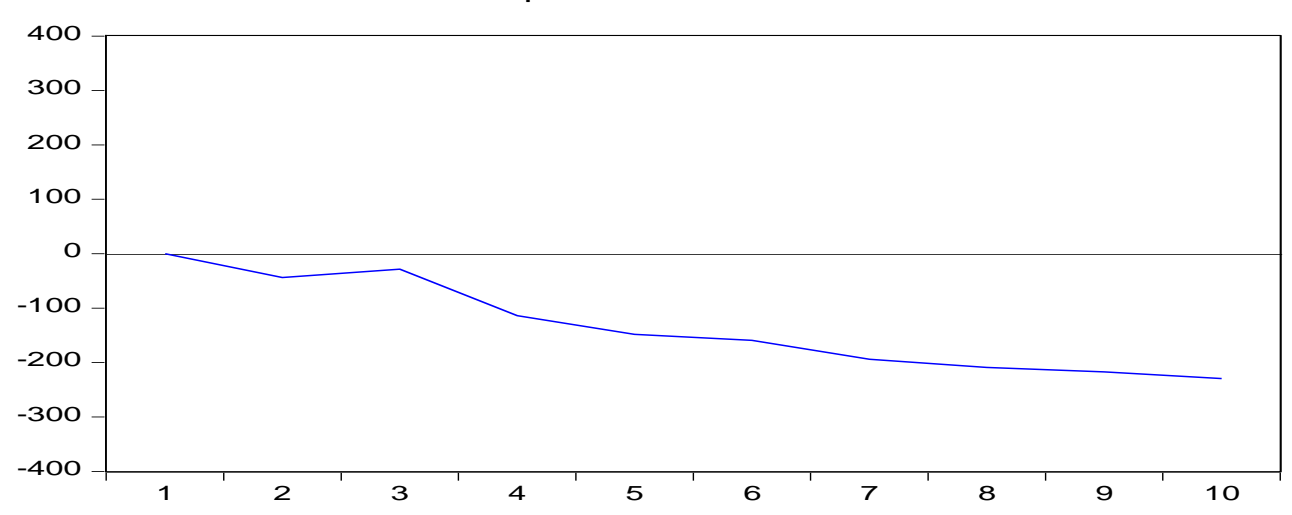

Resource: Data Processed

Figure 3 Response of ER to IMPORT

From the graph above we can see the response of exchange rate due to the change in import. Exchange rate has a negative response to the import from the $1^{\text {st }}$ period exchange rate was decreasing but at $2^{\text {nd }}$ period it try to increase but after $3^{\text {rd }}$ period till $10^{\text {th }}$ period exchange rate was decreasing significantly. It means that import causes of exchange rate as there is an inflow of foreign currency to Indonesia and increase the need of Rupiah which decrease the price of Rupiah against US Dollar. So government should help exporters and give them hand to improve the amount of exported goods which can strengthen the value of Rupiah.

Response of ER to $M 2$

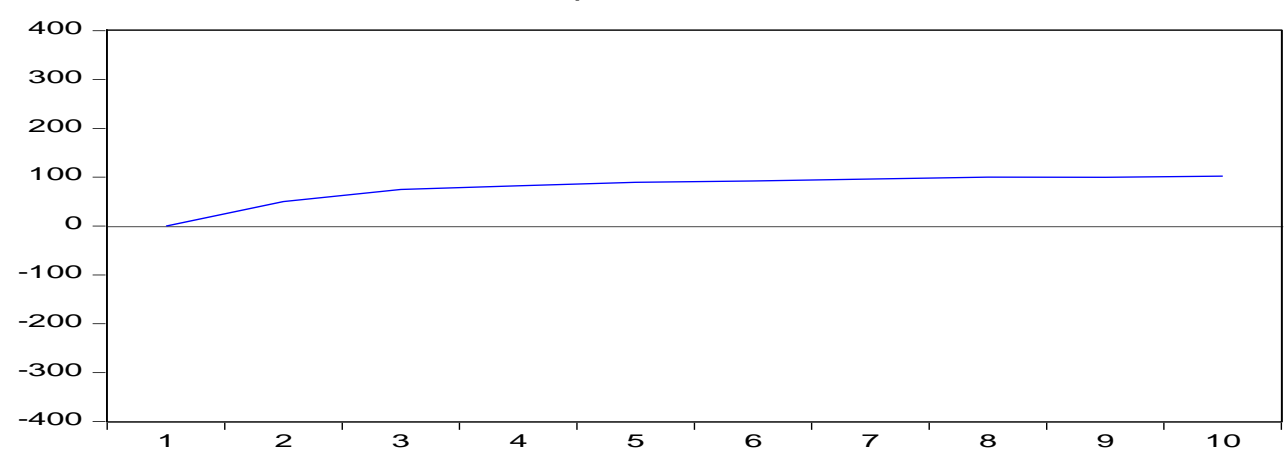

Resource: Data Processed

Figure 4 Response of ER to M2

From the graph above we can see the response of exchange rate to money supply. Exchange rate response to money supply is a positive response from the $1^{\text {st }}$ period till $3^{\text {rd }}$ period and it stabilize in the positive side till $10^{\text {th }}$ period. It means that money supply affect
Rupiah to decrease or with other side import was decreasing when rupiah was decreasing. So actually between Rupiah and import has some important role which response each other negatively, then government should pay their attention to both of them as our country still in need of import to survive. 


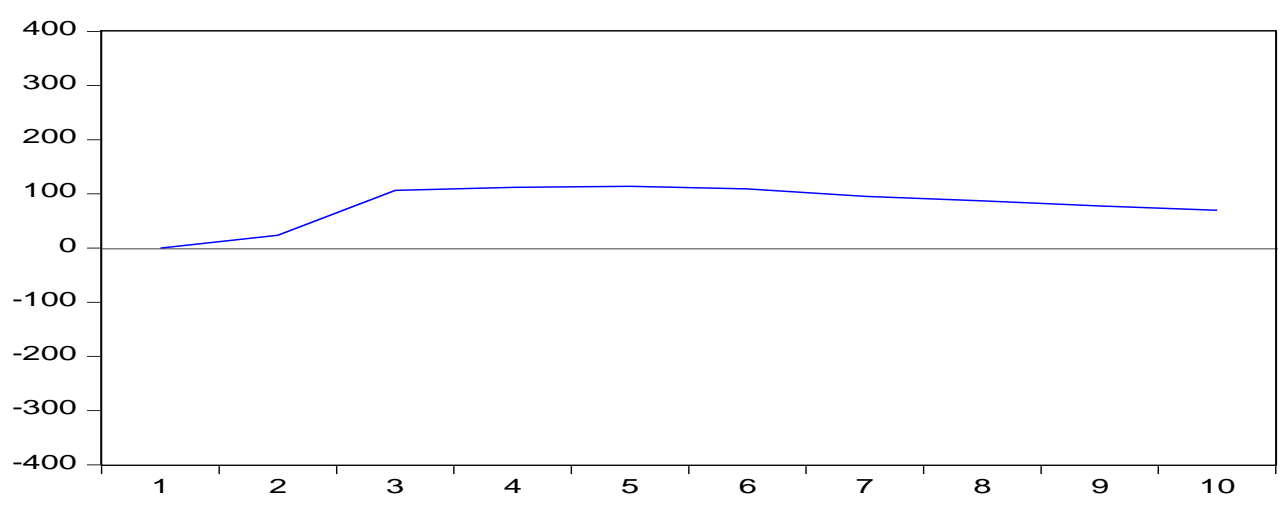

Resource: Data Processed

Figure 5 Response of ER to BIRATE

From the graph above we can see the response of exchange rate to Bank Indonesia rate. At $1^{\text {st }}$ period till middle of $2^{\text {nd }}$ period it increase but in stable term. After $2^{\text {nd }}$ period it increase dramatically till $3^{\text {rd }}$ period and then it stabilize and decreasing time to time but still in positive side till $10^{\text {th }}$ period. It means that the change in Bank Indonesia rate will affect positively to exchange rate but in the meantime it will stabilize slowly to reach the equilibrium point. So government should pay their attention to their monetary policy which includes the deciding of Bank Indonesia rate. Because it will affect the real market and money market eventually.
9. Forecasting Variance Decomposition.

Variance decomposition is used to detect the causal relations among the variables. It explains the degree at which the variable is explained by the shocks in all variables in the VAR system. Variance decomposition measures the percentage of forecast error of variation that is explained by another variable in the short-run dynamics and interactions. It does not provide information on how variables of interest respond to shocks or innovations in other variables. This study explores variance decomposition based on VAR specification. Table 5.10 below shows the result of variance decomposition, as follows.

Table 6 The result Variance Decomposition

\begin{tabular}{ccccccc}
\hline Period & S.E & DER & DEXP & DIMP & DM2 & DBRT \\
\hline 1 & 210.2362 & 100.0000 & 0.000000 & 0.000000 & 0.000000 & 0.000000 \\
\hline 2 & 309.8608 & 92.58361 & 2.227896 & 1.984458 & 2.613723 & 0.590318 \\
\hline 3 & 394.7830 & 82.25926 & 3.186523 & 1.737854 & 5.194153 & 7.622209 \\
\hline 4 & 478.1867 & 71.96127 & 4.008375 & 6.857557 & 6.497915 & 10.67488 \\
\hline 5 & 550.5112 & 63.29813 & 4.405857 & 12.42052 & 7.539937 & 12.33555 \\
\hline 6 & 616.6106 & 57.06958 & 5.139135 & 16.57123 & 8.244285 & 12.97576 \\
\hline 7 & 682.2231 & 51.46310 & 5.621225 & 21.63534 & 8.728271 & 12.55207 \\
\hline 8 & 744.2658 & 46.89091 & 5.986664 & 26.05459 & 9.150352 & 11.91748 \\
\hline 9 & 802.8150 & 43.30155 & 6.382514 & 29.72279 & 9.411816 & 11.18133 \\
\hline 10 & 859.3345 & 40.21222 & 6.674332 & 33.06704 & 9.627843 & 10.41856 \\
\hline
\end{tabular}

Resource: Data Processing

Table 6 above shows the result of variance decomposition of DER. In the $1^{\text {st }}$ period DER is 100 percent influenced by its own variable. Furthermore, the influence of DER variable itself decreases by $40.2 \%$ in the $10^{\text {th }}$ month. Table above also defines that in $1^{\text {st }}$ period DER variable is $0 \%$ influenced by DEXP, but in the last $10^{\text {th }}$ month DEXP influence DER to $6.7 \%$. Another explanation for DIMP variable which affect $0 \%$ in the $1^{\text {st }}$ period to DER, while 
in the last $10^{\text {th }}$ month DIMP affect DER to $33.1 \%$. For DM2 variable, it affects $0 \%$ in the $1^{\text {st }}$ period to DER and in the last $10^{\text {th }}$ month DM2 affect DER to $9.6 \%$. Lastly for DBRT, in the first period it affects DER $0 \%$ and in the last $10^{\text {th }}$ month DBRT affect DER to $10.4 \%$.

\section{CONCLUSION}

This study is started by the structural order of VAR to VECM. It started from Unit Roots Test and finished in Variance Decomposition. Based on the analysis and the test results above on the effects of export (EXP); import (IMP); money supply (M2); and Bank Indonesia rate (BRT) on exchange rate (ER), it can be concluded that:

1. In the long-run, some of the independent variables such as import and money supply have significant correlation to ER with positive and negative impact respectively while export and Bank Indonesia rate have not significant correlation to ER with negative and positive impact respectively. In the short-run, all of the independent variables have significant influence on ER except money supply, whereas import, money supply and bank Indonesia rate have a positive relationship to ER. Meanwhile, export has a negative influence to ER.

2. Based on the Impulse Responses and Forecast Error Variance Decomposition, the independent variable in which all variables are most capable to have a high shock to ER is import, because it gives a descent amount of the shock as shown on the forecast error variance decomposition and impulse responses in the previous period. It is suggested that the government has awareness towards the stabilization of the import markets.

\section{RECOMMENDATION}

Regarding to the study conclusion, the researcher submits recommendations for maintaining the stability of exchange rate as follows:

1. Based on the findings, we can conclude that all of independent variables significantly control the value of exchange rate in short and long run. Government should pay their attention toward export, import, money supply, and Bank Indonesia rate with the attention to the people reactions to the changes of those independent variable which the reaction will affect exchange rate respectively.

2. As Bank Indonesia rate is one element of monetary system government should confirm in the changes of it between reaching the goal of Bank Indonesia rate and maintaining the stability of exchange rate as the research find the positive and significant effect of Bank Indonesia rate toward exchange rate.

3. Because exchange rate is influencing trade balance as well the maintaining of it is a key to increase or decrease export as well with the policy of government to control the amount of exported and imported goods to reach the welfare for all of the society in Indonesia.

4. As Bank Indonesia rate is not significant in long-run government should pay attention to the desire of people in the real market as it can drive the people to do the economic activity. So government can improve another policy as using open market operation or reserve requirement ratio to stabilize exchange rate value in the future.

5. Muhammadiyah can take the research as the basis to reform the law no.24 year 1999 which talked about the flow of reserve and the exchange rate. The measurement that can be taken is BiRate was not significant in the long-run event depends on the result findings so there should be another thing that can control the volatility of exchange rate and make a stable value of it.

\section{REFERENCES}

Adebiyi, (2007), Does Money Tell Us Anything About Inflation in Nigeria?,Journal Singapore Economic Review, 52(1), 117134.

Ajija, Shochrul R. (2011). Cara Cerdas Menguasai EViews..Jakarta: Salemba Empat

Basuki, Agus dan Imamudin. (2014). Elektronik Data Prosesing (SPSS 15 dan EVIEWS 7). Yogyakarta : Danisa Media.

Gujarati, (1995), Basic Econometrics, 3rd ed., New York: McGraw-Hill.

Jeong, (2002), Intra and Inter-Continental Transmission of Inflation in Africa, 
Journal Applied Financial Economics, 12, 731-741.

Muchlas, Zainul and Agus R (2015). FaktorFaktor yang Mempengaruhi Kurs Rupiah Terhadap Dollar Amerika Pasca Krisis (2000-2010). Jurnal Jibeka. Volume 9 Nomor 1 Februari 2015: 76-86.

Palasari, RR Suci (2015). Efek Ekspor, Impor, Tingkat Inflasi dan Tingkat Suku Bunga terhadap Nilai Tukar Rupiah. UIN Malik Maulana Ibrahim:

Ulfia dan Aliasuddin (2011)."Hubungan Pendapatan dan Kurs di Indonesia" .Jurnal Ekonomi dan Pembangunan, 2(1): 3344

http://www.bi.go.id 